\title{
CLINICAL AND RADIOGRAPHIC EVALUATION OF BIODENTINE VERSUS FORMOCRESOL IN VITAL PULPOTOMY OF PRIMARY MOLARS (A RANDOMIZED CONTROL CLINICAL TRIAL)
}

\author{
Adel Abd El Aziem Elbardissy* and Manal Ahmed El Sayed*
}

\begin{abstract}
Background: The main objective of pulp therapy is to preserve the integrity and health of the teeth and their supporting tissues, as well as to maintain the pulp vitality. Formocresol (FC) is that fixing agent which is considered as gold standard and used as pulpotomy medicament for primary teeth for decades. Several concerns had been reported about the use of FC. These concerns push new medicaments to be used for pulpotomy purposes. Among these medicaments is Biodentine (BD).
\end{abstract}

Aim of the study: To compare FC and BD clinically and radiographically when used for pulpotomy of vital primary molars.

Study Design : A randomized control clinical trial (split mouth and double blind) was conducted on 43 (4-6 years-old) children with decayed vital mandibular primary molars which were treated by pulpotomy using both medicaments. All treated teeth were followed for one year (at 3, 6,9 and 12 months clinically and at 6 and 12 months radiographically).

Results: BD showed $100 \%$ clinical and radiographic success at all follow up timing, however FC showed $85.4 \%$ and $78 \%$ radiographic success at 6 and 12 months follow up period. By clinical evaluation FC showed $95.1 \%$ success at the end of follow up period with no significant difference.

Conclusions: BD as a pulpotomy medicament showed $100 \%$ clinical and radiographic success with no statistically significant difference with FC clinically. However a statistically significant difference was recorded between both medicaments regarding their radiographic success rate where $\mathrm{BD}$ was superior.

KEY WORDS: Pulpotomy, Primary Teeth , Formocresol, Biodentin, Success rate

\section{INTRODUCTION}

Treatment of primary teeth with vital pulp exposure is a topic of great interest in the field of pediatric dentistry.
The main objective of pulp therapy is to preserve the integrity and health of the teeth and their supporting tissues, and to maintain the vitality of the pulp ${ }^{(1,2)}$.

*Associate Professor of Pediatric Dentistry, Faculty of Dentistry, Cairo University 
Pulpotomy of primary teeth is defined as amputation of the coronal pulp and treatment of the remaining vital radicular portion with a long term clinically successful medicament. An ideal medicament used for pulpotomy should have a bactericidal effect, enhance healing of the radicular pulp tissue, biocompatible and does not interfere with physiologic root resorption ${ }^{(3)}$.

A wide range of medicaments and techniques have been used for pulpotomy purposes with different modes of action including formcresol (FC), ferric sulfate, calcium hydroxide, laser application, electro surgery and MTA ${ }^{(4-8)}$.

FC is that devitalizing and fixing agent which was introduced to dentistry since 1904 with full concentration of Buckley's formula (19\% formaldehyde, $35 \%$ cresol, and $15 \%$ glycerin in distilled water). These concentrations were proved to be toxic to connective tissue cells ${ }^{(3,9)}$.

A five times diluted formula of Buckley's formocresol, was suggested and used since 1968 , it was concluded that formocresol in this concentration does not interfere with prolonged recovery of connective tissue, and might suppress the inflammatory response ${ }^{(10)}$.

Although its high success rate, availability and cost effectiveness, the use of formocresol in dental treatment was a matter of considerable debate because of its possible mutagenic, carcinogenic and toxic effects. a study have claimed that FC is "likely no longer suitable for use in Dentistry" and "should be abandoned" up to the limit that the International Agency for Research on Cancer classified medicaments containing formaldehyde as carcinogenic and should not be used for humans in June $2004^{(11)}$.

More over, in European Union countries all dental products containing formaldehyde have been withdrawn from the dental market ${ }^{(12)}$.

However a considerable number of other studies showed no evidence of significant risks of using formocresol in pulp therapy for primary teeth, also the American Academy of Pediatric Dentistry still recommend its use for pulp therapy and still used and taught in many dental schools worldwide ${ }^{(5,9,13)}$.

As a result of this debate about $\mathrm{FC}$, other medicaments had been raised and used for pulpotomy. Among them, calcium silicate based cements which were used in pulp therapy techniques such as pulp capping and apexogenesis. These medicaments have good sealing ability and biocompatibility ${ }^{(14,15)}$.

Mineral trioxide aggregate (MTA) was introduced in 1993 as a root end filling material ${ }^{(16)}$ .It has been suggested as a bio regenerative and bio inductive material with a very high success rate that could be comparable to FC or even superior. So it has been used in pulpotomy procedures since $2001^{(17)}$ as concluded from a systematic review and a meta-analysis of randomized clinical trials ${ }^{(7)}$.

But MTA has some drawbacks such as its difficulty in handling, prolonged setting time, tooth discoloration and low cost effectiveness ${ }^{(18-20)}$.

Biodentine (BD) was introduced to dentistry, manufactured by Septodont and it has been available since 2010. It is considered as dentine substitute and a high-purity calcium silicate based material formed of powder and liquid ${ }^{(21)}$. Biodentine powder is mainly composed of tricalcium silicate, calcium carbonate and zirconium oxides while the liquid contains calcium chloride as the setting accelerator and water reducing agent ${ }^{(22)}$.

BD has been used first in endodontic field due to its promising physical properties, perfect sealing ability, ease of manipulation and short setting time in addition to very important findings that it does not cause tooth discoloration ${ }^{(23,24)}$ as well as excellent bactericidal effect due to its high alkalinity $(\mathrm{pH}=12)^{(25,26)}$.

Biodentine and MTA were compared as pulpotomy agents for primary teeth. Clinical and radiographic evaluations were performed with $100 \%$ success for both of the MTA and Biodentine groups 
or with a minor superiority of MTA that was none significant ${ }^{(27-29)}$.

A randomized, split-mouth, double-blind, controlled clinical trial was carried out to compare clinical and radiographic success rates of biodentine versus form cresol in pulpotomy of primary molars. After six months follow up period the results showed an equal success rate of $100 \%{ }^{(26)}$.

Clinical studies comparing biodentine and formocresol success rates in pulpotomy of human primary teeth are scarce. The purpose of this clinical study was to compare the clinical and radiographic success rate of biodentine with that of formocresol for pulpotomy of human primary molars over a period of one year.

\section{MATERIALS AND METHODS}

\section{Study design}

Randomized clinical trial, double blinded using split mouth technique.

\section{Study setting}

This study was carried out in Pediatric Dentistry Department-Faculty of Dentistry-Cairo UniversityEgypt.

\section{Patients}

Patients recruited for this study were selected according to the following criteria:

- Healthy children between 4 and 6 years of age with two matched bilateral deep carious primary mandibular first or second molars.

- No evident clinical symptoms of pulpal necrosis or pulp degeneration such as pain on percussion, spontaneous pain, history of swelling or presence of sinus tract.

- No pathologic or physiologic mobility.

- No radiographic evidence of internal and external resorption, pulp stone, and interradicular or periapical lesions (Preoperative radiograph).
- The remaining tooth structure would be restorable with a stainless steel crown.

- Bleeding time after amputation of the coronal pulp tissue was within normal limits (5 minutes).

\section{Sample size calculation}

Using sealedenvelop.com, ${ }^{(30)}$ the online sample calculator, sample size was calculated assuming the null hypothesis that biodentine and formocresol have an average success rate of 95,99\% and 87.8 $\%$ respectively $(26,31,32,33)$. Thus planning a binary outcome non inferiority trial with a difference of $8.19 \%$, then 76 primary molars (38 per group) are required to be $90 \%$ sure that the upper limit of a one-sided $95 \%$ confidence interval will exclude a difference in favor of the standard group of more than $10 \%{ }^{(34)}$.

With an estimation of $10 \%$ annual dropout, sample size was set to 86 primary molars (43 per group) ${ }^{(35)}$.

Forty three children with the matching criteria of patient selection were included in this study.

Research Ethics Committee approval was obtained from Faculty of Dentistry Cairo University. Detailed treatment plan and procedures were explained to the parents and informed written consent s were obtained before practical work.

\section{Randomization}

Using 4 times folded papers in which one of the tested materials was written (43 paper for each material) contained in a closed white envelops (43 envelop in each one folded paper of each tested materials were placed), the selected two matched bilateral deep carious primary mandibular molars were randomly allocated to one of the tested materials.

When guardians agreed for their child to participate in the trial, an envelope was drowned and patient personal data was written on it. 
At the time of treatment of the first tooth in each patient, one of the folded papers was taken from the envelope and the type of the dressing material was recorded.

Trial participants and outcome assessors were blinded to the type of materials used in each tooth.

\section{Clinical treatment}

1- Preoperative photographs and radiographs were recorded for all selected cases as base line data (fig. 1)

2- Local anesthesia was given at the side of the tooth selected for treatment.

3- Then the teeth were isolated using rubber dam.

4- Dental caries was removed with a slow-speed round bur No.5, before pulpal exposure. The entire roof of the pulp chamber was then removed using round bur No.5 mounted in a water-cooled high speed turbine. The coronal pulp was amputated using a sharp spoon excavator and the pulp chamber was irrigated with a light flow of normal saline. Moistened cotton pellets were placed over the pulp stumps, and high pressure was applied (1-5 min). When the cotton pellets were removed homeostasis was apparent.

5- If bleeding was not controlled within 5 minutes the case had been excluded from the study.

6- application of tested materials:

\section{a) Formocresol group:}

sterile cotton pellets were placed in a solution of 1:5 diluted Buckley's formocresol (Buckley's Formocresol, Sultan Healthcare) and immediately blotted dry on sterile gauze. The cotton pellet was placed directly over the radicular pulp stumps and left for 5 minutes. It was then removed and pulp stumps were covered with zinc oxide eugenol (ZOE) paste (DPI, Mumbai, India). The cavity was filled with thick mix of zinc oxide and egenol (fig. 2).

\section{b-Biodentine group:}

Biodentine capsule was gently tapped on a hard surface (to diffuse powder); five drops of liquid from the single dose dispenser were poured into the capsule which was placed in a triturator for $30 \mathrm{sec}$. The mixture of biodentine was then introduced into the pulp chamber using amalgam carrier, The cavity was filled with Glass ionomer cement (Riva self cure, SDI, Australia) ( fig. 3).

In both groups teeth were restored with stainless steel crowns (3M, ESPE, Unitek, United States). Cemented with glass ionomer cement (GC Fuji I, GC America, Alsip, IL, USA). An immediate postoperative radiograph using periapical film size 2 (Speed D Film, Kodak, United States) was taken (fig 4).

\section{Follow up protocol:}

The children were recalled for clinical evaluation at 3, 6, 9 and 12 months and for radiographic evaluation at 6 and 12 months.

\section{Evaluation of the trial outcomes:}

\section{a) clinical evaluation:}

Treatment was considered clinically successful when there was absence of spontaneous or nocturnal pain, abscess, fistula or pathologic mobility.

\section{b) Radiographic evaluation:}

Treatment was considered radiographically successful when there was absence of periapical or inter-radicular radiolucency, external or internal root resorption or calcific metamorphosis in the radicular pulp canal.

Treatment was considered as a failure when one or more of the previously mentioned signs was detected. Time for teeth with pulpotomy failure was defined as the time elapsed between treatment and the first visit in which pathologic finding was detected. 


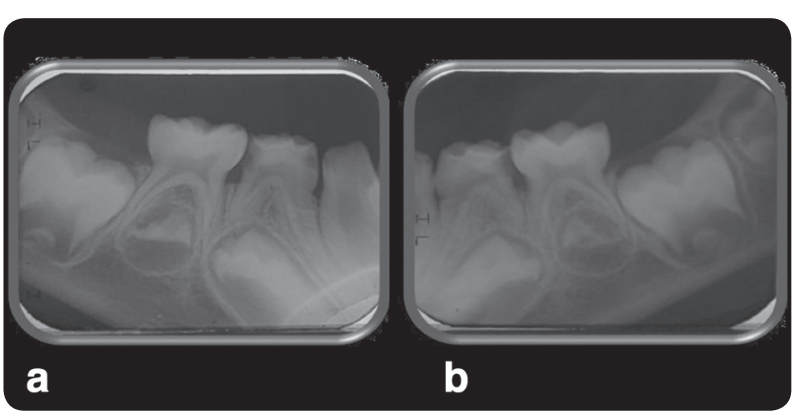

Fig. 1: Preoperative radiographs for primary molar to be treated with biodentine (a) and formocresol (b).

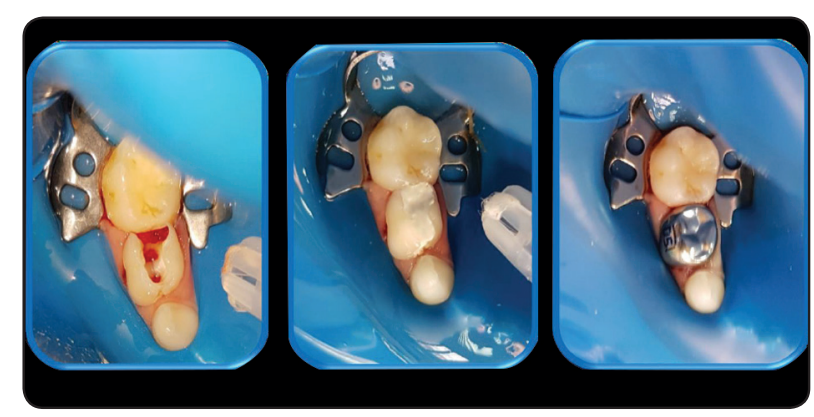

Fig. 3: Biodentine pulpotom

Radiographic evaluation was done by two blinded assessors independently.

The inter examiner agreements was calculated using Kappa scores.

- Data were collected and statistically analyzed.

\section{RESULTS}

43 children (both boys and girls whom ages ranged from 4 to 6 years old) with bilateral deeply decayed mandibular primary molars were participated in this study, where 86 primary molars were classified into two groups .One of them included 43 primary molars which were treated by biodentine (test group) while the other was the contralateral 43 primary molar and were treated by our gold standard FC (control group).

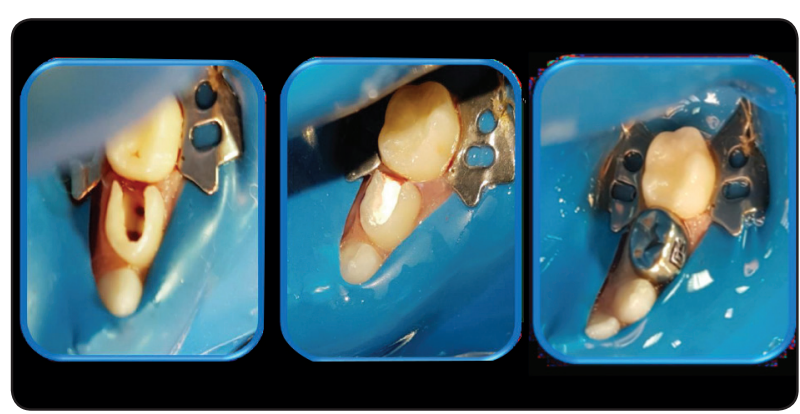

Fig. 2: Formocresol pulpotomy.

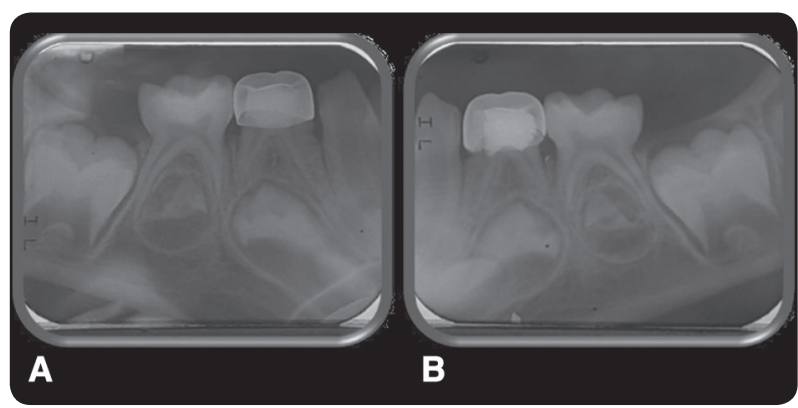

Fig. 4: Immediate Postoperative radiographs for primary molar treated with biodentine (a) and formocresol (b).

These children were followed up for one year with 3 months interval (at 3,6,9 and 12 months ) clinically, while at 6 and 12 months radiographically. At the beginning of the follow up 2 cases were dropped out and excluded from the total number of children ,so the authors completed this study with 41 till the end of the follow up period.

\section{Clinical Evaluation:}

At 3 months the whole cases (41) showed $100 \%$ clinical success with both materials ( biodentine and formocresol) . Two cases of mobility were recorded in the FC group one of them at 6 and the other at 12 months follow up period with a percentage of success $95.1 \%$ and failure $4.9 \%$. On the other hand biodentine showed $100 \%$ clinical success till the end of follow up period but with no statistically significant difference ( table 1 fig. 5 ) . 
TABLE (1) Descriptive statistics and results of Wilcoxon signed rank test for comparison between clinical success in the two groups

\begin{tabular}{|c|c|c|c|c|c|c|}
\hline \multirow[b]{2}{*}{ Time } & \multirow[b]{2}{*}{ Criteria } & \multicolumn{2}{|c|}{$\begin{array}{l}\text { Formocresol } \\
\qquad(n=41)\end{array}$} & \multicolumn{2}{|c|}{$\begin{array}{l}\text { Biodentine } \\
(\mathrm{n}=41)\end{array}$} & \multirow{2}{*}{$P$-value } \\
\hline & & n (41) & $\%$ & n (41) & $\%$ & \\
\hline \multirow{3}{*}{3 months } & Pain & $0 / 41$ & 0 & $0 / 41$ & 0 & $\mathrm{NC}^{\dagger}$ \\
\hline & Abscess or fistula & $0 / 41$ & 0 & $0 / 41$ & 0 & $\mathrm{NC}^{\dagger}$ \\
\hline & Mobility & $0 / 41$ & 0 & $0 / 41$ & 0 & $\mathrm{NC}^{\dagger}$ \\
\hline \multicolumn{2}{|l|}{ Clinical evaluation } & $41 / 41$ & 100 & $41 / 41$ & 100 & $\mathrm{NC}^{\dagger}$ \\
\hline \multirow{3}{*}{6 months } & Pain & $0 / 41$ & 0 & $0 / 41$ & 0 & $\mathrm{NC}^{\dagger}$ \\
\hline & Abscess or fistula & $0 / 41$ & 0 & $0 / 41$ & 0 & $\mathrm{NC}^{\dagger}$ \\
\hline & Mobility & $1 / 41$ & 2.4 & $0 / 41$ & 0 & 0.317 \\
\hline \multirow{2}{*}{ Clinical evaluation } & Success & $40 / 41$ & 97.6 & $41 / 41$ & 100 & \multirow{2}{*}{0.317} \\
\hline & Failure & $1 / 41$ & 2.4 & $0 / 41$ & 0 & \\
\hline \multirow{3}{*}{9 months } & Pain & $0 / 41$ & 0 & $0 / 41$ & 0 & $\mathrm{NC}^{\dagger}$ \\
\hline & Abscess or fistula & $0 / 41$ & 0 & $0 / 41$ & 0 & $\mathrm{NC}^{\dagger}$ \\
\hline & Mobility & $1 / 41$ & 2.4 & $0 / 41$ & 0 & 0.317 \\
\hline \multirow{2}{*}{ Clinical evaluation } & Success & $40 / 41$ & 97.6 & $41 / 41$ & 100 & \multirow{2}{*}{0.317} \\
\hline & Failure & $1 / 41$ & 2.4 & $0 / 41$ & 0 & \\
\hline \multirow{3}{*}{12 months } & Pain & $0 / 41$ & 0 & $0 / 41$ & 0 & $\mathrm{NC}^{\dagger}$ \\
\hline & Abscess or fistula & $0 / 41$ & 0 & $0 / 41$ & 0 & $\mathrm{NC}^{\dagger}$ \\
\hline & Mobility & $2 / 41$ & 4.9 & $0 / 41$ & 0 & 0.157 \\
\hline \multirow{2}{*}{ Clinical evaluation } & Success & $39 / 41$ & 95.1 & $41 / 41$ & 100 & \multirow{2}{*}{0.157} \\
\hline & Failure & $2 / 41$ & 4.9 & $0 / 41$ & 0 & \\
\hline
\end{tabular}

\section{*: Significant at $P \leq 0.05, N C^{\dagger}$ : Not Computed because the variable is constant}

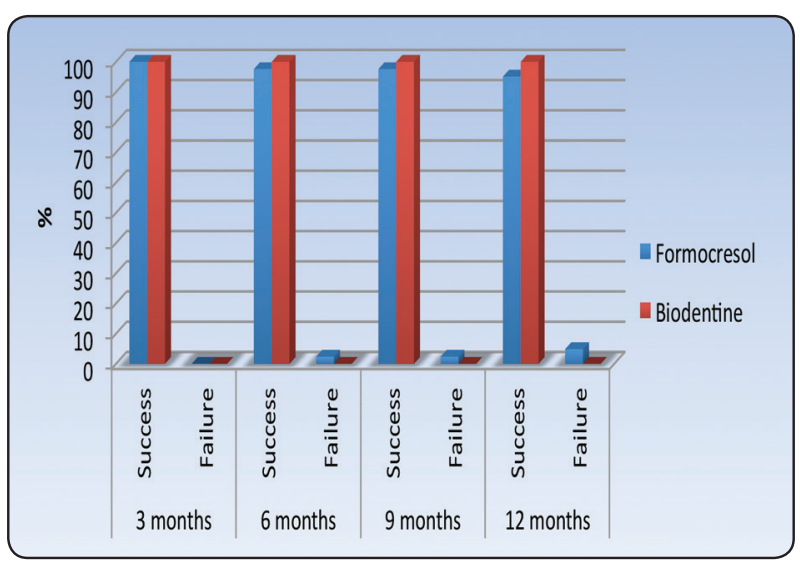

Fig. (5): Bar chart representing comparison between clinical success in the two groups

\section{Radiographic Evaluation:}

By comparing the radiographic success in both groups the results of this study showed that at 6 months FC showed $85.4 \%$ radiographic success and $14.6 \%$ radiographic failure (6 cases 2 of them represented with radiolucency and 4 with internal root resorption). By time and at the end of follow up period the success rate of FC decreased to reach $78 \%$ and failure $22 \%$ as the number of cases with radiolucency increased to be 3 and the resorption cases increased to be 6 .However BD showed $100 \%$ radiographic success with a statistically significant difference where p- value was 0.014 and 0.003 at 6 and 12 months consecutively (table 2, fig. 6,7,8). 
TABLE (2) Descriptive statistics and results of Wilcoxon signed rank test for comparison between radiographic success in the two groups.

\begin{tabular}{|c|c|c|c|c|c|c|}
\hline \multirow[b]{2}{*}{ Time } & \multirow[b]{2}{*}{ Criteria } & \multicolumn{2}{|c|}{$\begin{array}{l}\text { Formocresol } \\
\qquad(\mathrm{n}=41)\end{array}$} & \multicolumn{2}{|c|}{$\begin{array}{l}\text { Biodentine } \\
(\mathrm{n}=41)\end{array}$} & \multirow{2}{*}{$P$-value } \\
\hline & & $\mathrm{N}$ & $\%$ & $\mathrm{~N}$ & $\%$ & \\
\hline \multirow{3}{*}{6 months } & Radiolucency & $2 / 41$ & 4.9 & $0 / 41$ & 0 & 0.157 \\
\hline & Resorption & $4 / 41$ & 9.8 & $0 / 41$ & 0 & $0.046^{*}$ \\
\hline & Calcific metamorphosis & $0 / 41$ & 0 & $0 / 41$ & 0 & $\mathrm{NC}^{\dagger}$ \\
\hline \multirow{2}{*}{$\begin{array}{l}\text { Radiographic } \\
\text { evaluation }\end{array}$} & Success & $35 / 41$ & 85.4 & $41 / 41$ & 100 & \multirow{2}{*}{$0.014 *$} \\
\hline & Failure & $6 / 41$ & 14.6 & $0 / 41$ & 0 & \\
\hline \multirow{3}{*}{12 months } & Radiolucency & $3 / 41$ & 7.3 & $0 / 41$ & 0 & 0.083 \\
\hline & Resorption & $6 / 41$ & 14.6 & $0 / 41$ & 0 & $0.014 *$ \\
\hline & Calcific metamorphosis & $0 / 41$ & 0 & $0 / 41$ & 0 & $\mathrm{NC}^{\dagger}$ \\
\hline \multirow{2}{*}{$\begin{array}{l}\text { Radiographic } \\
\text { evaluation }\end{array}$} & Success & $32 / 41$ & 78 & $41 / 41$ & 100 & \\
\hline & Failure & $9 / 41$ & 22 & $0 / 41$ & 0 & $0.003^{*}$ \\
\hline
\end{tabular}

\section{*: Significant at $P \leq 0.05, N C^{\dagger}$ : Not Computed because the variable is constant}

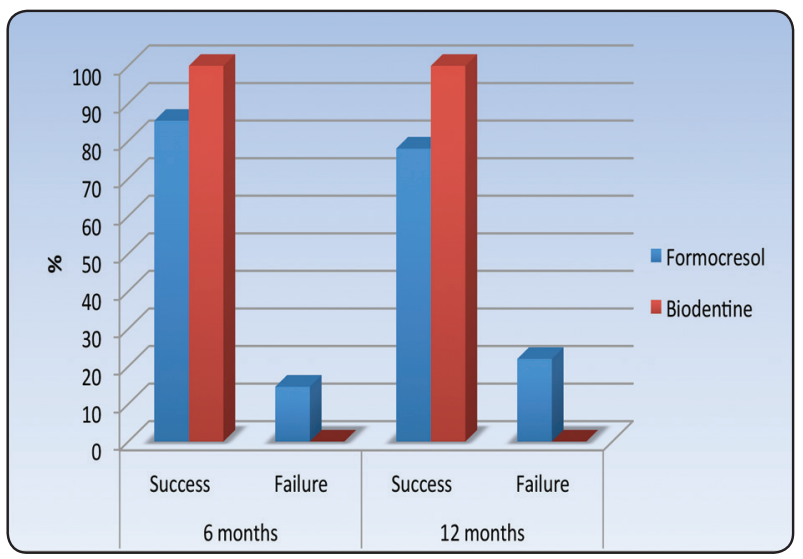

Fig. (6): Bar chart representing comparison between radiographic success in the two groups 


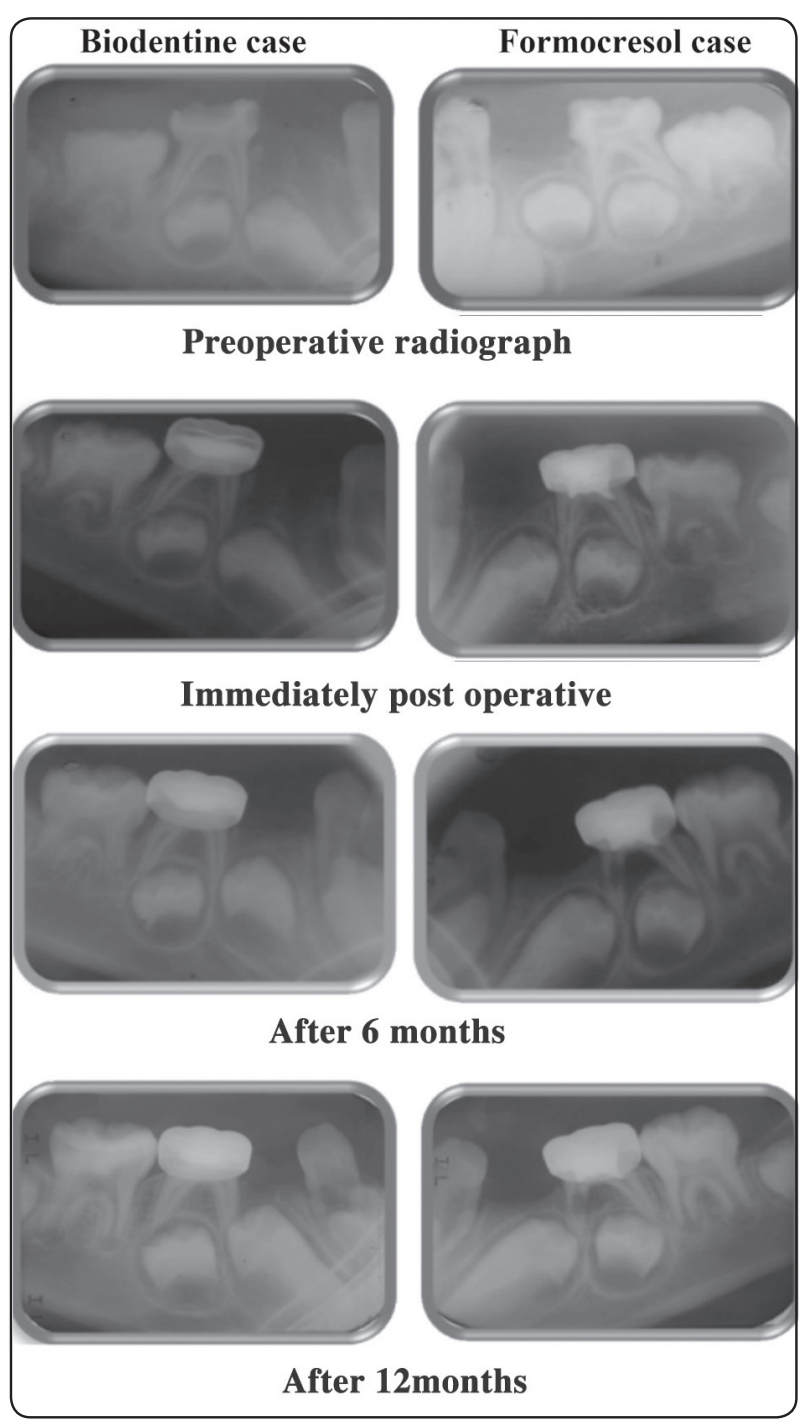

Fig. (7) Radiographic progress over a period of 12 months for primary molars treated with formocresol or biodentine

\section{DISCUSSION}

Pulpotomy is one of the most important and accepted techniques used for treatment of asymptomatic primary teeth with carious pulp exposure ${ }^{(36)}$.

FC is a pulpotomy medicament used for devitalization of vital pulp tissues with a great bactericidal effect and very high recorded success rates ${ }^{(14,18)}$ in addition to its availability and coast effectiveness so, it is considered as a gold standard, still used and officially taught in many dental schools ${ }^{(13)}$.

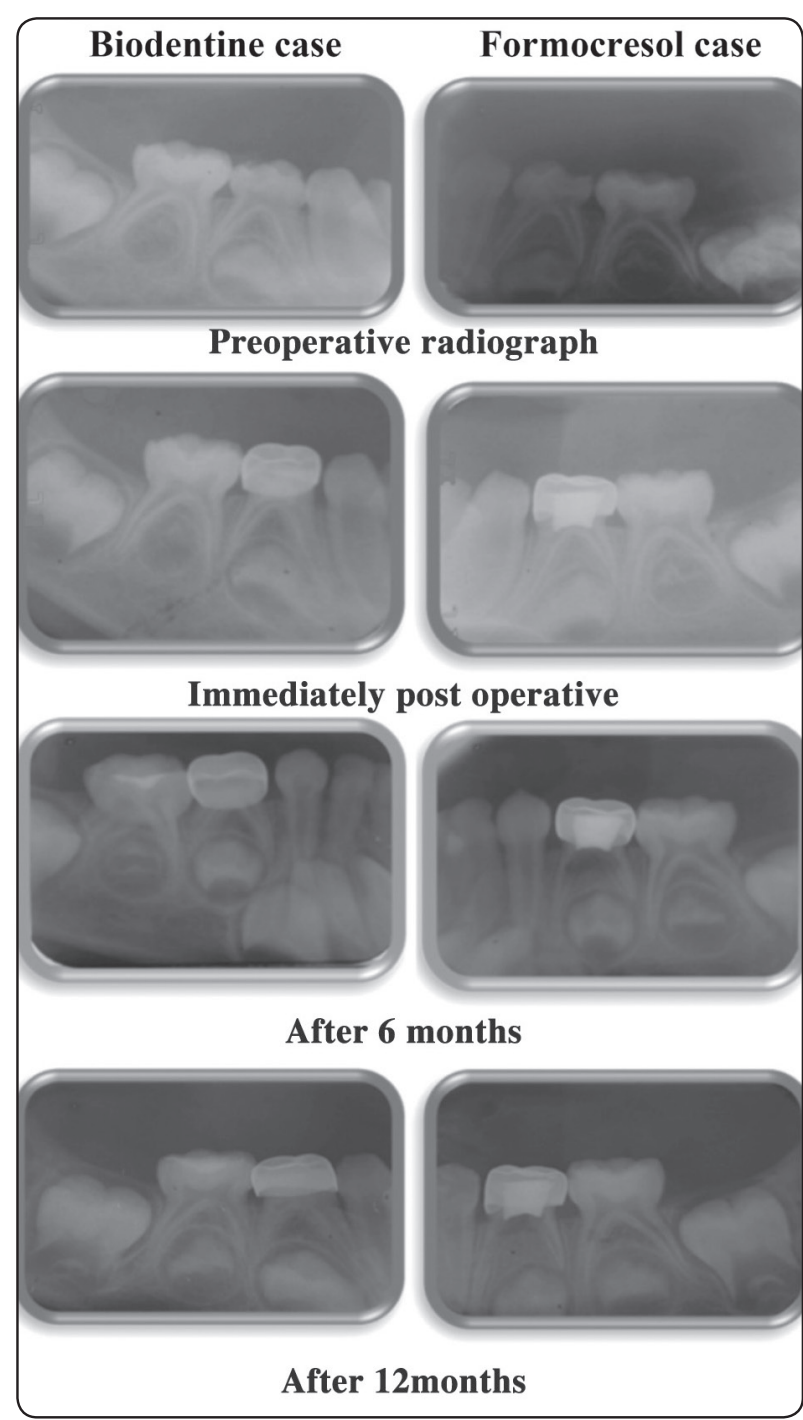

Fig. (8) Radiographic progress of another case over a period of 12 months for primary molars treated with formocresol or biodentine.

As a result of the concerns about the safety of FC by several authors ${ }^{(13,14,18,37)}$ alternative materials have been introduced to the dental market with higher safety properties. Among these materials are MTA and BD.

In this study the authors compared FC as a gold standard versus BD for pulpotomy of vital primary molars in an attempt to find a safer medicament to be used as an alternative to FC bearing in mind the safety and general health of children. 
In the present study 4 to 6 years old children were involved in order to be more co-operative with easier behavior management as well as to conduct the study on primary molars away from the age of normal physiologic root resorption.

Split mouth technique was applied in order to standardize the general conditions of the child, dietary habits, oral hygiene practices, immune response and tissue reactions, in addition to the availability of the child to follow up and evaluate the success rates of both materials ${ }^{(27)}$.

The mandibular molars were treated in this study as they are usually more accessible for practical work as well as their radiographic interpretation is much more easier without superimposition which enables the investigators to identify any radiographic changes ${ }^{(38)}$.

All selected primary molars were pulpotomized using either FC or BD, then covered by stainless steel crowns as they were proved to be the most durable, protective and long standing restorations ${ }^{(26,39)}$.

All treated primary molars were evaluated for clinical success rate at 3,6,9,12 months. While radiographic evaluation was done after 6 and 12 months.

Two cases were dropped out of the total number (43) with a percentage of $4.7 \%$ while 41 cases were highly committed and completed their follow up till the end of 12 months. These two cases were not able to attend the follow up appointments due to difficulty in transportation and inconvenient time for their parents to bring them. Also it was observed that some dental patients once they were pain relieved, they did not come for follow up.

By comparing both materials the results of this study showed that there was no statistical difference regarding the clinical success rates during all follow up periods. BD showed $100 \%$ clinical success rate while FC showed 100\%, 97.6\%, $97.6 \%$ and $95.1 \%$ clinical success at 3, 6,9, and 12 months respectively ( table 1 fig. 5).
FC showed two cases of pathologic mobility one of them at 6 months and the other at 12 months follow up. These results were supported by Farsi et al $^{(40)}$ and Carrotte and Waterhouse ${ }^{(41)}$ who explained this unfavorable response on the bases that when FC comes in direct contact with vital pulp for five minuets , this time is very short to produce complete fixation leaving the pulp in a state of chronic inflammation which results in pathologic mobility. Waterhouse et al ${ }^{(42)}$ and Vargas and Packham ${ }^{(43)}$ explained the occurrence of pathologic mobility due to the chronic irritation of the pulp tissues from the eugenol content of the freshly prepared zinc oxide eugenol paste which may result in internal and or external root resorption.

On the other hand the results of this study showed that there was a statistical significant difference between FC and BD treated cases regarding radiographic success rates. BD showed $100 \%$ radiographic success rate during the whole follow up period. While FC showed $85.4 \%$ and $78 \%$ success rate at 6 and 12 months follow up respectively (table 2 fig.6).

Two cases of radiographic failure with FC (radiolucency in the furcation area) were recorded at 6 months, this number increased to three cases at 12 months follow up. This results goes in agreement with Berger $^{(44)}$ and Magnusson ${ }^{(45)}$ who attributed the furcation involvement to the smaller molecular size of FC so it can penetrate into the furcation area through the accessory pulp canal and the very thin and permeable pulpal floor causing such inflammatory response. This finding was also supported by other studies ${ }^{(14,43,46,47,48)}$.

Another four cases of radiographic failure with FC (internal and or external root resorption) were recorded at 6 months follow up. This number increased to six cases at 12 months follow up. This result goes in line with the opinion of Berger ${ }^{(44)}$ and Magnusson (45) who found that in FC pulpotomy there is an internal root resorption with or without external root resorption. They also reported that the percentage of failure with FC pulpotomy increased with time. 
The presence of internal root resorption was attributed to the eugenol content of the capping material which can lead to certain vascular changes that may result in chronic inflammation with the formation of granulation tissue and differentiation of osteoclast - like odontoclasts that act on the inner wall of the root leaving internal resorption ${ }^{(49)}$.

No calcific metamorphosis was seen radiographically during the follow up period neither with $\mathrm{FC}$ nor BD cases. This finding goes in agreement with Haval et al ${ }^{(49)}$. Meanwhile this finding was a source of debate between the researchers being considered as a failure due to deviation from the normal structure of the pulp tissue to calcific metamorphosis ${ }^{(42,46,47,48)}$ while other researchers considered calcific metamorphosis as an extra activity of odontoblast like cells that retain their vitality and continue their role in dentin formation in an attempt to repair and heal after a stimulus ${ }^{(50-52)}$.

High success rates of BD seen in this study both clinically and radiographically are in agreement with the previous studies done on primary molars ${ }^{(30,53,54)}$. Attempts to preserve pulp vitality of the remaining pulp tissues of the primary teeth treated with pulpotmy seems to be more successful both clinically and radiographically.

\section{CONCLUSIONS}

According to the results of this study, the following conclusions could be withdrawn :

1- BD (as a pulpotomy agent) showed 100\% clinical and radiographic success, however FC showed more clinical than radiographic success through out one year follow up .

2- No statistical significant difference was recorded by comparing $\mathrm{FC}$ and $\mathrm{BD}$ regarding their clinical success, however BD was superior.

3- Statistical significant difference was recorded by comparing both materials regarding their radiographic success where FC showed more radiographic failure which increased by time.

\section{RECOMMENDATIONS}

According to the results of this clinical study we can recommend:

1- The use of BD as a pulpotomy agent in an attempt to avoid the drawbacks of FC.

2- More clinical and histological studies with longer follow up period.

3- More studies should be conducted in our developing countries to evaluate the cost effectiveness of BD.

\section{REFERENCES}

1- American Academy of Pediatric Dentistry (AAPD), "guidelines on pulp pulp therapy for for primary and immature permanent tooth", 2014; 244-252

2- Simancas-Pallares MA, Diaz-Caballero AL. and LunaRicardo LM.:Mineral trioxide aggregate in primary teeth pulpotomy: A systematic literature review. Med Oral Patol Oral Cir Bucal 2010; Nov.15(6): 942-946

3- Vargas K.G.,Fuks A.B. and Peretz B.: Pediatric Endodontics, Current concepts in pulp therapy for primary and young permanent teeth, 1st. ed. Switzerland, Springer International Publishing 2016; 51-7o

4- Trairatvorakul C. and koothiratrakarn A.: Calcium hydroxide partial pulpotomy is an alternative to formocresol pulpotomy based on 3-years randomized trial. International Journal of Pediatric Dentistry, 2012; 22 (5): 382-389

5- Erdem A.P. Guven Y., Balli B., et al.: Success rate of mineral trioxide aggregate, ferric sulfate and formocresol pulpotomies. "A 24 month study". Journal of Pediatric Dentistry, 2011; 33 (2): 165-170

6- Aeinehchi M., Dadvand S., Fayazi S.. and Bayat- Movahed S.: Randomized controlled trial of mineral trioxide aggregate and formocresol for pulpotomy in primary molar teeth. International Endodontic Journal, 2007; 40 (4): 261-267

7- Shirvani A. and Asgary S.: Mineral trioxide aggregate versus formocresol pulpotomy : A systematic review and meta-analysis of randomized clinical trials.Clinical Oral Investigations, 2014; 18 (4): 1023-1030

8- Junior E.,S.,Vitcel M.,E.,B. and Oliveira L.B.: "Evidence of pulpotomy in primary teeth comparing MTA, calcium hydroxide, ferric sulfate and electro surgery with 
formocresol".European Archives of Pediatric Dentistry, 2015; 16 (4): 303-312

9- Peng L., Tan, H. and Zhou X.: Evaluation of formocresol versus mineral trioxide aggregate primary molar pulpotomy: a meta-analysis. Oral Surg. Oral Med. Oral Pathol. Oral Radiol. and Endodontics, 2006; (102): 40-44

10- Marawa AP., Straffon LH., Han SS. and Carpron RE.: Clinical evaluation of pulpotomies using dilute formocresol. J. Dent. Child., 1975; 42(5): 360-363

11- International Agency for Research on Cancer "IARC" classifies formaldehyde as carcinogenic to humans. Press release no. 153, 15 June 2004 ,Google search.

12- Celine Cheong, Gloria Wong, Mark K. and Nigel M. King: Is formocresol still safe for use in Pediatric Dentistry ? (Part II). Dental Asia.July/ Augest 2008

13- Marghalani AA., Omar S. and Chen JW.:Clinical and radiographic success of mineral trioxide aggregate compared with formocresol as a pulpotomy treatment in primary molars: A systematic review and meta-analysis. J Am Dent Assoc., 2014; 145(7): 714-721

14- Koubi S., Elmirini H., Koubi G., Tassery H. and Camps $\mathrm{J}$.: Quantitative evaluation by diffusion of micro leakage in aged calcium silicate based open sandwich restorations. Int J. Dent. 2012; (2): 1-6

15- Kusum B., Rakesh K. and Richa K.: Clinical and radiographical evaluation of mineral trioxide aggregate, biodentine and propolis as pulpotomy medicamentsin primary teeth. Rest Dent Endod. 2015; 40 (4): 276-285

16- Torabinejad, M. Watson, TF. and Pitt Ford TR.:Sealing ability of mineral trioxide aggregate when used as a root end filling material, J Endod.1993; (19): 591-595

17- Eidelman,D.Odont, G., Holan, A. and Fuks B.: "Mineral trioxide aggregate vs. formocresol in pulpotomized primary molars :A preliminary report" Journal of Pediatric Dentistry, 2001; 23(1): 15-18

18- Suskynski,J. Zealand, C. Botero, T. el al: Comparison of grey mineral trioxide aggregate and diluted formocresol in pulpotomized primary molars, a 6-24 month observation. Pediatr. Dent. 2012;(34): 120- 128

19- Santos, A.D. Moraes, J.C.S. Araujo, E.B., Yukimitu, K., and ValerioFilho, V.: "Physico-chemical propertiesof MTA and novel experimental cement "International Endodontic Journal, 2005; 38(7): 443-447

20- Torabinejad,M. and Chivian N.: Clinical applications of mineral trioxide aggregate. Journal of Endodontics 1999; 25 (3): 197-205
21- Butt, N., Talwar S., Chaudhry S., Nawal RR. Yadav S. and Ball A.: A comparison of physical and mechanical properties of mineral trioxide aggregate and biodentine. Indian Journal of dental research ,2014; 25(6):692-697

22- Laurent P., Camps J. and iDe Me o M Dejou J.: About I Introduction of specific cell responses to Ca3sio5-based posterior restorative materials. Dental Materials, 2008; 24: 1486-1494

23- Ahmed HM.and Abbott PV.: Discoloration potential of endodontic procedures and materials. Areview. Int Endod J, 2012; 45: 883-897

24- Akhtar M., Rana SA., Rana MJ., Parveen N. and Kashif M.: Clinical and radiological success rates of Biodentine for pulpotomy in children. International J. of Contemporary Medical Research, August 2016; 3(8):2334-2336

25- Malkondu O., Kazandag K. and Kazazoglu E.: A review on biodentine ,a contemporary dentine replacement and repair material. Biomed Research International, on line article ID: $160951,10,2014$

26- Al Amoudi N. and El Meligy O.: Comparison between biodentine and formocresol for pulpotomy of primary teeth: A randomized clinical trial. Quintessence international, May 2016; 47(7): 571-580

27- Doyle T., Casas M., Kenny D. and Judd p.: Mineral trioxide aggregate produces superior outcomes in vital primary molar pulpotomy.Pediatr Dent. 2010; (32): 41-47

28- Bachoo IK., Seymour D. and Brunton P.: A biocompatible and bioactive replacement for dentine: is this a reality? The purpose and uses of a novel calcium-based cement. $\mathrm{Br}$ Dent J.2013;Jan214(2):E5. Doi:10.1038/sj.bdj.2013.57

29- Shamkhalov G., Ivanova E., Dmitrieva N. and Akhmedova Z. : Comparative study of antimicrobial activity of Biodentine and Rootdent cements and Futurabond HP adhesive.J Stomatol 2013; 92: 37-39

30- https://www.sealedenvelope.com/power/

31- Farooq NS, Coll JA, Kuwabara A, Shelton P. Success rates of formocresol pulpotomy and indirect pulp therapy in the treatment of deep dentinal caries in primary teeth. Pediatr Dent. 2000 Jul-Aug;22(4):278-86.

32- S.E. Jabbarifar DD, A. A. Khademi DD**, D. Ghasemi DD. Success Rate of Formocresol Pulpotomy versus Mineral Trioxide Aggregate in Human Primary Molar Tooth. Journal of Research in Medical Sciences 2004; 6: 304-307

33- J. A. DEAN, R. B. MACK, B. T. FULKERSON \& B. J. SANDERS1. Comparison of electrosurgical and formocresol pulpotomyprocedures in children. International Journal of Paediatric Dentistry 2002; 12: 177-182 
34- Blackwelder WC. "Proving the Null Hypothesis" in Clinical Trials. Control. Clin. Trials 1982; 3:345-353.

35- Prashant K and Supriya B. sample size calculation. Int JAyurveda res. 2010 Jan-Mar:55-57.

36- Guven Y,. Aksakal SD., Avcu N., Tuna EB. And Aktoren O.: Success rates of pulpotomies in primary molars using calcium silicate - based materials : A randomized control trial BioMed Res International, article ID: 4059703, available on : https://doi.org/10.1155/2017

37- Casas M., Kenny D., Judd P. and Johnston D.: Do we still need formocresol in pediatric dentistry ? J. Clin Dent Ass., 2005; 71: 749-751

38- Zhang L., Freeman L., Nakamura J.,Hecht SS., Vandenberg JJ. Et al : Formaldehyde and leukemia: Epidemiology, potential mechanisms and implications for risk assessment Environmental and Molecular Mutagenesis, 2010 ;51: 181-191

39- Mohammed G., Jerin F. and Jebin S.: Pulpal diagnosis of primary teeth :Guidelines for clinical practice. Bangladesh Journal of dental Research and Education. Available on: http://wwwbangalajol.info/index.php/BJDRE Article view /162481/11507

40- Farsi N., Al Amoudi N., Balto K. and Mushayt A.: Success of mineral trioxide aggregate in pulpotomized primary molarsL. Clin Peiatr. Dent. 2005,29: 307-311

41- Carrotte PV. And Waterhouse PJ.: Aclinical guide to endodontics - update part 2, BDJ Nature Publishing Group 2009, 206 (3): 133-139

42- Waterhouse PJ., Nunn JH. And Whitworth JM.: An investigation of the relative efficacy of Buckley's formocresol and calcium hydroxide in primary molar vital pulp therapy. BDJ. 2000; 188: 32-36

43- Vargas KG. and Packham B.: Radiographic success of ferric sulphate and formocresol pulpotomies in relation to early exfoliation . Pediatr Dent. 2005; 27: 233-237

44- Berger JE.: A review of erroneously labeled "mummification" techniques of pulp therapy. Oral Surgery, 1972; 34: 131-144
45- Magnusson BO.: Therapeutic pulpotomies in primary molars with formocresol technique .A clinical and histological follow up.Acta Odontol Scand.,1978; 36: 157-165

46- Ansari G. and Ranjpour M.:Mineral trioxide aggregate and formocresol pulpotomy of primary teeth. A 2 year follow up. International Endodontic Journal,2010; 43:410-418

47- Huth KC., Paschos E., Hajek AL.,Khatar N., Hollweck R., Hickel R. et al : Effectiveness of 4 pulpotomy techniques - Randomized control trial. Journal of Dental Research, 2005; 84: 1144-1148

48- Casas M., Kenny D., Judd P. and Johnston D.:Long term out comes of primary molar ferric sulfate pulpotomy and root canal therapy. Pediatr Dent., 2004; 26: 44-48

49- Havale R., Anegundi RT., Indushekar KR. and Sudha P.: Clinical and radiographic evaluation of pulpotomies in primary molars with formocresol, glutaraldehyde and ferric sulfate. OHDM, 2013; 12,(1): 24-31

50- Kalaskar RR. And Damle SG.: Comparative evalualion of lyophilized freeze dried platelet derived preparation with calcium hydroxide as pulpotomy agent in primary molars.J. Indian Soc. Pedod.Prev. Dent.2004; 22,(1): 24-29

51- Oliveria TM., Morelli ABS., Sakai VT. Et al: Clinical, radiographic and histologic analysis of the effects of pulp capping materials used in pulpotomies of human primary teeth. Eur. Arch. Pediatr. Dent. 2013; 14: 65-71.

52- Soundappan S., Sundaramurthy JL. and Natanasabapathy V.: Biodentine vs. mineral trioxide aggregate vs. intermediate restorative material for retrograde root end filling : an invitro study.J. Dent., 2014; 11: 143-149

53- Juneja P. and Kullkarni S.: Clinical and radiographic comparison of biodentine ,mineral trioxide aggregate and formocresol as pulpotomy agents in primary molars. Eur. Arch. Pediatr. Dent. 2017; 18: 271-278

54- Fouad WA. And Youssef R.: Clinical and radiographic assessment of vital pulpotomy in primary molars using mineral trioxide aggregate and a novel bioactive cement. Egyptian Dental Journal, 2013; July (59): 3007-3013 